\title{
架空送電線の風騒音対策
}

\section{Countermeasures for Wind Noise from Overhead Transmission Line}

\author{
䆶川 弘*1 伊本杉男 ${ }^{* 2}$ 仰木一郎*3 北嶋知樹*4 田辺一夫*5
}

Hiroshi KUBOKAWA, Sugio IMOTO, Ichirou OGI, Tomoki KITASHIMA, Kazuo TANABE

1. はじめに

架空送電線は自然環境下に晒されているため、風に よるギャロッピング振動や微風振動など動的な空気 力学現象に対する振動対策が行われてきた。

一方、架空送電設備の超高圧化、大容量化と市街地 への接近に伴い、強風時に送電設備から発生する風騒 音が線路環境面から重要な課題となってきている。

電線から発生する風騒音は $100 \mathrm{~Hz}$ 前後のジェット 騒音に似た低周波騒音であり、既設送電線からの風騒 音対策として電線の周りにつる巻き状にアルミ線を 巻きつけるスパイラルロッド対策が開発された。1)

その後、新設線路の風音対策用として電線形状自体 に突起を有する低風音電線が開発された。2)

更に、送電電圧の高い $1,000 \mathrm{kV}$ 送電線路用として、 風騒音対策と降雨雪時の電気的なコロナ騒音を協調 して低減する低騒音電線が実用化された。3)
送電線路からは電線風騒音以外にも、がいし風音4) や鉄塔風音 $\left.{ }^{5}\right)$ 発生し、これらの対策も実施された。

本稿では、架空送電線の風騒音対策技術全般に関し て、新技術も含めて紹介を行う。

\section{2. 電線風音}

\section{1 研究の経緯}

送電線路の風騒音が認識され始めたのは、昭和 47 年頃であり、送電容量の増大に伴う送電線路の多導体 化の時期に符合している。

当時は送電線路から発生するジェット機騒音のよ うな「ゴー」という騒音発生源が送電線か鉄塔か分か らないため、現地での観測からスタートした。

騒音の発生源特定のため、複数のマイクロホンを設 置して、各マイクロホンに到達する騒音の時間差を解 析して送電線が騒音源であることが確認された。11

\footnotetext{
* 1 株式会社ジェイ・パワーシステムズ 架空送電線事業部 開発部長 General Manager, R\&D Dept. Overhead Transmission Line Division, J-Power Systems

*2 関西電力株式会社 電力システム技術センター 送電グループ 課長 Manager, Transmission Line Group, Power System Engineering Center, THE KANSAI ELECTRIC POWER CO.,INC.

*3 中部電力株式会社 流通本部 工務部 送電グループ スタッフ課長

Manager, Transmission Line Section Electrical Engineering Department, Chubu Electric Power CO., INC

*4 東京電力株式会社 工務部送変電建設センタ 既設特殊設計評価グループ 副長

Deputy Manager, Design Evaluation Group for Existing Transmission Towers Transmission \& Substations Construction Center Power System Engineering Department, Tokyo Electric Power Company

* 5 財団法人電力中央研究所 狛江研究所 電気絶縁部 上席研究員

Senior Research Engineer Director, Electrical Insulation Department, KOMAE Research Laboratory, Central Research Institute of Electric Power Industry
} 


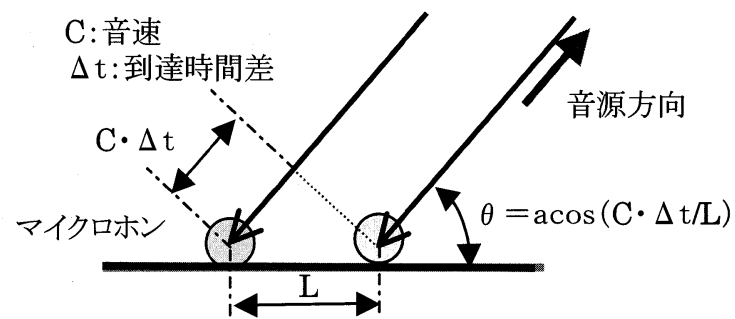

図 1.騒音源特定のための現地観測

現地観測から電線が騒音源であると確認されたため、 風騒音対策を目的に低騒音風洞が建設され、風向風速 や電線サイズ、導体数などをパラメータとした電線風 騒音の定量的な解析が実施された。1)

風洞実験でのメカニズム検討などに基づき、スパイ ラルロッド径や巻き付けピッチの最適化による電線風 騒音対策技術が確立された。

\section{2 電線風騒音の特徵}

電線から発生する風音としては、配電線の「ヒュー」 という音が聞き慣れており、冬の風物詩となっている。

電線風音は電線外径によって音色が変化し、超高圧 の架空送電線の場合には電線外径が $20 \sim 50 \mathrm{~mm}$ と太 くなるため、「ゴー」という $50 〜 250 \mathrm{~Hz}$ のジェット機 に似た低周波側に卓越を有する音色となる。

低周波音に関しては感じ方に個人差が多いものの、 周囲の暗騒音レベルが低い場合には、普段聞き慣れな いこともあり、多少耳障りと感ずる場合がある。

超高圧送電線は大型化し地上高が高く、電線も多導 体化し本数が多いため、地上で風が弱くても上空は強 風が作用し、地形や暗騒音により $1,000 \mathrm{~m}$ 離れても認識 される場合がある。

低騒音風洞での電線風音の発生周波数を測定した例 が次図であり ${ }^{1)}$ 、風速の増加に伴い周波数と発生ル゙ル の増加傾向が認められる。

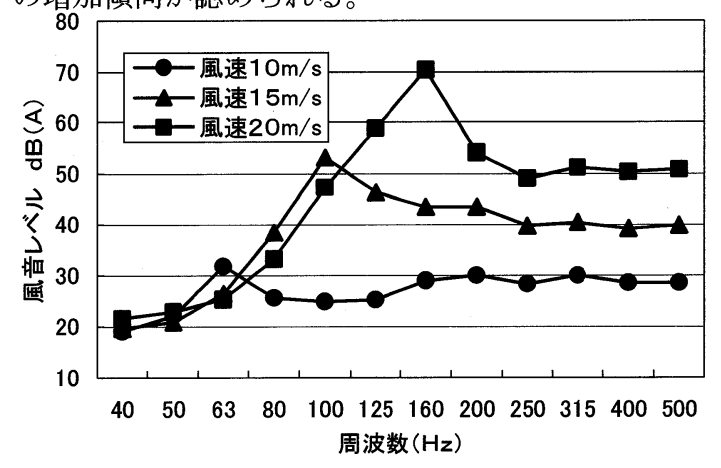

図 2. 架空送電線から発生する風音の周波数分析 $\left(A C S R 410 \mathrm{~mm}^{2}\right.$ （外径 $\left.28.5 \mathrm{~mm}\right) \times 4$ 導体の場合）

\section{3 電線風音発生メカニズム}

電線から発生する風音の騒音レ゙゙ル(以下「風音レ゙ル と呼ぶ）は流体要因により単導体と多導体の場合で発 生レベルが大きく異なる。

\subsection{1 単導体の場合}

電線の周りの流れを円柱でモデル化したものが下 図である。円柱表面には粘性の大きな境界層流れがあ り、流れが後流側に進む際に境界層内の圧力上昇で円 柱から流れが剥離し、後方に渦を形成する。

電線風音は後流側の渦の影響を受けた電線表面流れ の剥離に伴なう変動揚力 $\mathrm{F}_{\mathrm{L}}$ と変動抗力 $\mathrm{FD}$ に起因する 流体騒音であり ${ }^{6)}$ 、エオルス音と呼ばれる。円柱の場 合変動抗力成分は小さく、圧力変動は主として電線上 下の剥離点付近で発生し、音響双極子と見なされる。

円柱で発生する渦に関する流体力学的な解析 ${ }^{7)}$ によ ると、渦の位相は円柱の長手方向にある相関長さを持 っている。層流的な流れの場合、相関距離が長く、変 動揚力が大きくなることで音響強度が増大する。

風音レベルを低減するには、揚力変動成分を小さく するか、電線表面に突起などの粗度を形成して相関距 離を短くする必要がある。

\section{揚力 $F_{L}(t)=F_{0}+\Delta F_{L} \cdot \sin (\omega t)$}

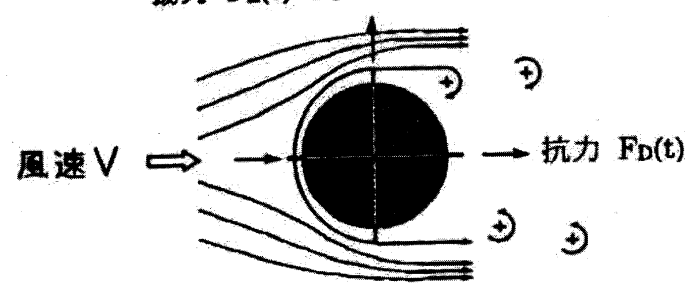

図 3. 円柱周りの流れのモデル化

\subsection{2 多導体の場合}

電線が単導体の場合には、圧力変動が、電線上下付 近に存在するため、音響双極子型の音源となる。

一方、多導体の場合には、上流側の渦の影響で電線に あたる風が変動し、双極子の軸が時間的場所的に変動 する。また、多導体の場合には、上流側電線と後流側 電線の渦が干渉し、電線表面での圧力変動が増幅され、 風音レベルが増大する傾向が認められる。 8

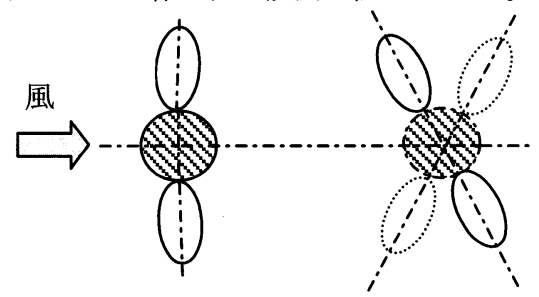

図 4. 単導体と多導体の電線表面の音源形状 
導体配列による電線風音レベルを比較したものが下 図であり、垂直配列の場合が単導体の 2 倍 $(3 \mathrm{~d} \mathrm{~B})$ で あるのに対して、水平配列は導体間隔が素導体径の 6 倍程度で 20 倍 $(13 \mathrm{~d} \mathrm{~B}) 、 400 \mathrm{~mm}$ 間隔の場合には 4 倍 （6dB）程度になる。9)

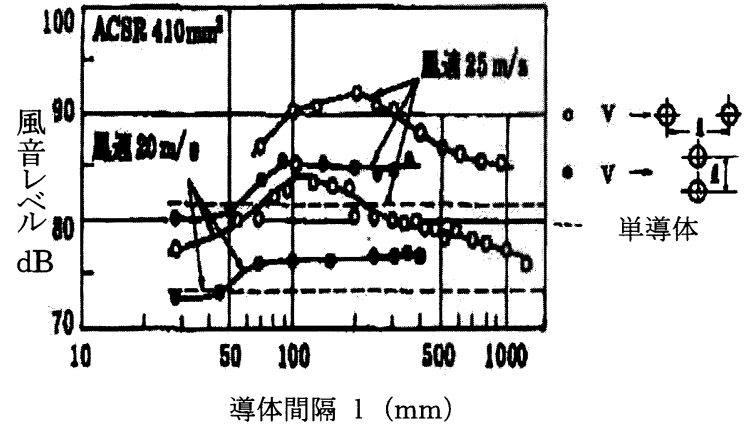

図 5. 導体配列による電線風音への影響

\section{4 電線風音の特性}

\subsection{1風向風速特性}

電線風音は風が電線に直角に作用するときに最大 のレベルとなり、斜風になるにしたがって風音レベル も小さくなる傾向がある。

一方、風音レベルは Phillips ${ }^{7)}$ の検討から風速の 6 乗 で増加することが理論的に導かれており、実験でもこ の傾向が確認されている。

風向 $\theta$ 、風速 $\mathrm{V}$ とすると風音レベルは $10 \log (\mathrm{V} \sin$ $\theta)^{6}=60 \log (V \sin \theta)$ に比例して増加する。 ${ }^{1)}$

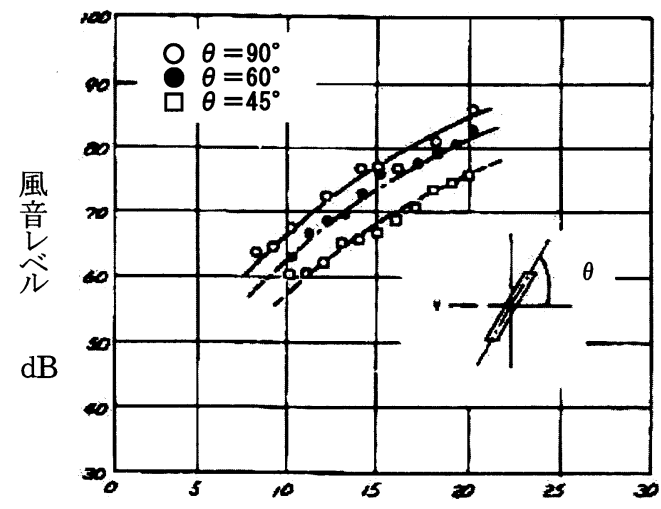

風速 $\mathrm{V}(\mathrm{m} / \mathrm{s})$

図 6. 風向風速と風音レベルの関係

\subsection{2 伝搬特性}

電線風音は電線の剥離点近傍から上下方向に伝搬 の指向性を有しており、受音点との距離 $\mathrm{r}$ 、なす角度 を $\phi$ とすると $10 \log (\cos \psi / \mathrm{r})$ の関係で減衰すること が風洞やフィールド観測で確認されている。9)

風音伝搬特性は送電線の風下側、風上側で有意差が ないことが風洞やフィールド観測で確認されている。

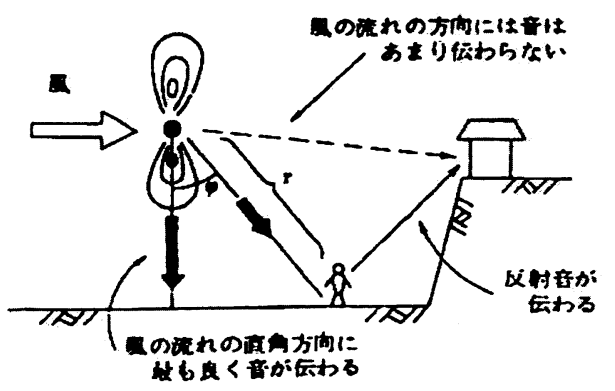

図 7. 電線風音の指向性

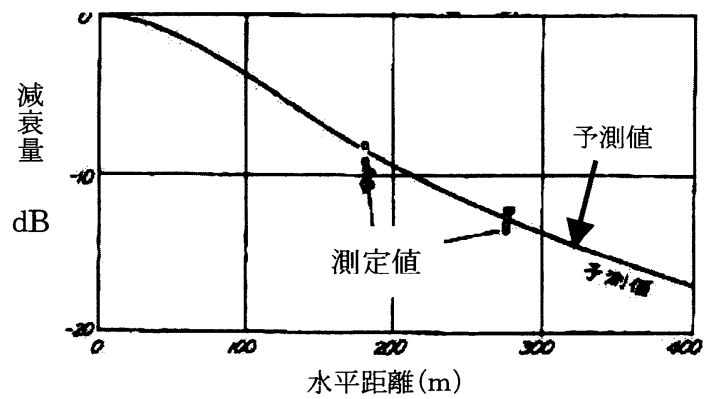

図 8. 風音の伝搬特性

\section{5 電線風音予測技術}

電線風音の影響範囲予測手法が開発され、対策必要 箇所の選定やルート選定に反映されている。

\subsection{1 風洞実験}

電線から発生する風音レベル予測のため、電線サイ ズ、導体本数、導体配列をパラメータとして、電線種 類別に発生レベルが求められている。

電線種類別の発生レベルは下図の方法で低騒音風洞 を用いて測定され、 $1 / 3$ オクターブ分析器を用いて、 風音の実態が解析されている。

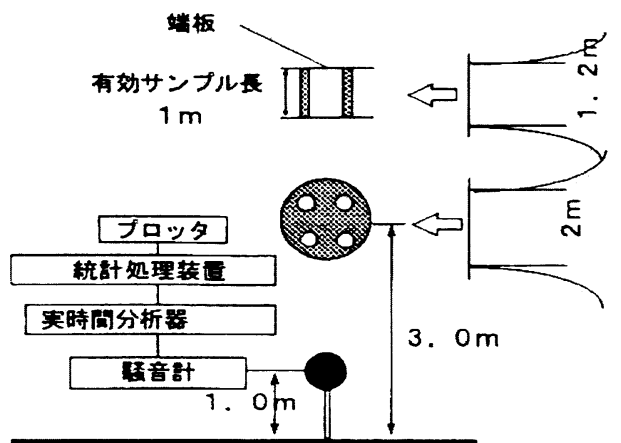

図 9.風洞実験による電線風音レベルの測定

\subsection{2 環境を配慮した線路設計}

風洞実験等により電線風音予測式が求められてお り、電線サイズ、導体数、電線地上高、風向風速等が 分かれば影響範囲の予測が可能である。

送電線路に基淮高さで $10 \mathrm{~m} / \mathrm{s}$ の風速が作用した場合 の風音影響範囲を計算した例が図 10 であり、過去の多 数の現地観測で予測と実測の一致が確認されている。 


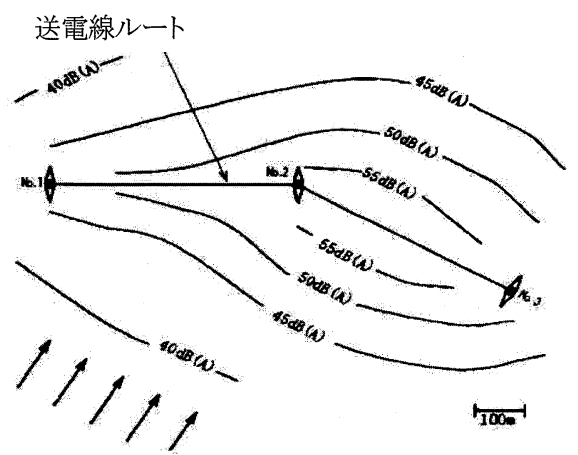

風速 $\mathrm{V}=10 \mathrm{~m} / \mathrm{s}$

図 10 . 電線風音影響範囲の予測計算例

\section{3. 電線風音対策技術}

\section{1 スパイラルロッド対策}

\subsection{1 標準対策方法}

電線風音は 1972 年（昭和 47 年）頃から送電線の多 導体化などに伴い発生し始めた。低騒音風洞を用いた 検討により下図のような、境界層流れを乱流化して、 揚力変動や長手方向の均一な 2 次元流れを抑止するス パイラルロッド対角 2 条巻き対策が㥶用化された。 ${ }^{11}$

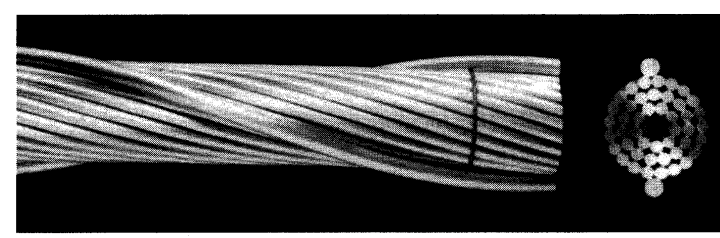

図 11. スパイラルロッド風音対策 （標淮対策： 対角 2 条巻き対策）

\subsection{2超高圧線路向け対策方法}

超高圧線路で電線表面電位傾度 $\mathrm{Gmax}$ が $12 \mathrm{kV} / \mathrm{cm}$ を 越えるような箇所にスパイラルロッド対角 2 条巻き対 策を実施すると、降雨時のコロナ八厶音レベルが上昇 するため、水滴部分の電界を緩和する目的で密着 2 条 巻き対策、対角密着 2 条巻きが実用化された。

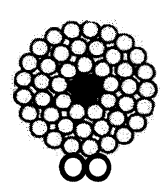

(密着 2 条巻き)

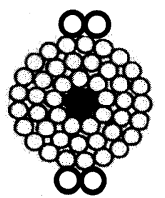

（対角密着 2 条巻き）
図 12. 超高圧線路向けスパイラルロッド対策

\section{2 低風音電線}

\subsection{1 開発背景}

送電線の多導体化に伴い風音レベルが上昇し、スパ イラルロッドによる風音対策の必要性が増加したが、 設計面や施工面での課題も出てきた。

設計面ではスパイラルロッド巻付けによる自重、風
圧荷重の増加、施工面では導体数の増加による巻付け 作業員の確保、コストが問題となった。

このような背景のもと、電線自体に風音やコロナ騒 音を低減機能を有した新規電線への開発ニーズが高く なった。風音予測精度も向上し、対策箇所の選択も可 能となったため、低風音電線の開発が着手された。

\subsection{2 電線形状の検討}

電線風音は電線表面に突起を形成して、境界層流れ を乱流化することで、揚力変動を抑制して、風音レベ ルの低減が可能である。

境界層の薄い円柱をベースにして、2 導体モデルに 着いて、突起の高さと開き角をパラメータとして風音 低減特性が検討された。

風音の低減量で評価すると、下図から最適な突起高 さは $2.5 \mathrm{~mm}$ 、突起部開き角は $45^{\circ}$ 程度となる。 ${ }^{2)}$

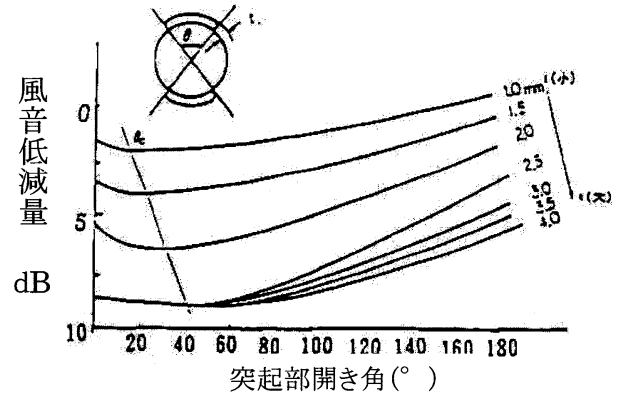

図 13. 突起部の形状と風音レベル低減量の関係 （ $\phi 38$ 円柱モデル、水平 2 導体配置の場合）

\subsection{3 風音特性}

表面を平滑にして境界層を薄くして突起を形成す ることで、従来のスパイラルロッドの外径の $1 / 3$ 程度 で同様な風音低減効果を得る事が出来た。

低風音電線 NS-TACSR810 は 1987 年（昭和 62 年） に初めて $500 \mathrm{k} \mathrm{V}$ 送電線に適用された。

低風音電線の風音低減効果は下図 ${ }^{2)}$ のように、従来 のスパイラルロッド対策と同等の効果が確認された。

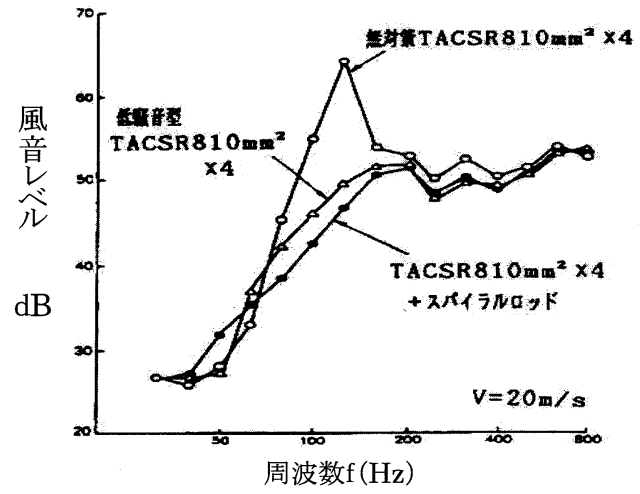

図 14. 低風音電線 NS-ACSR810 $\mathrm{mm}^{2}$ の風音特性 


\subsection{4 各種低風音電線}

低風音電線はスパイラルロッド対策のような重量、 風圧の増加がなく、鉄塔強度アップが不要のため、コ ストダウン効果があり新設線路での採用が増えている。

ACSR410〜ACSR1160 mm²の低風音電線形状を示す。

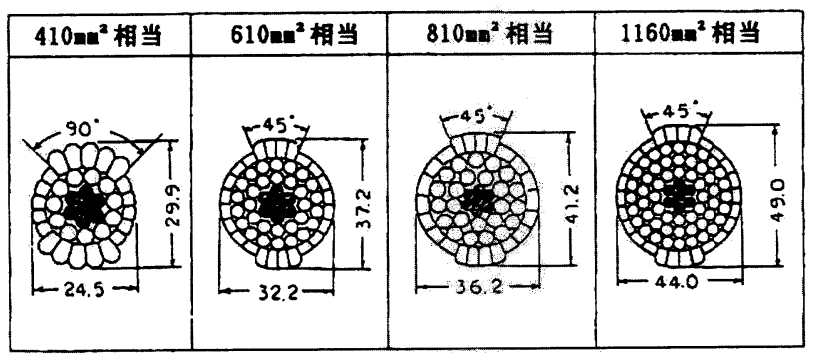

図 15. 電力線用低風音電線の形状 ${ }^{8)}$

\subsection{5 低風音架空地線}

避雷用の架空地線は 1 条であり、多導体電線のよう な後流渦の影響を受けないため、難着雪特性を優先す る構造として突起高さは $1.5 \mathrm{~mm}$ が採用された。 ${ }^{8}$

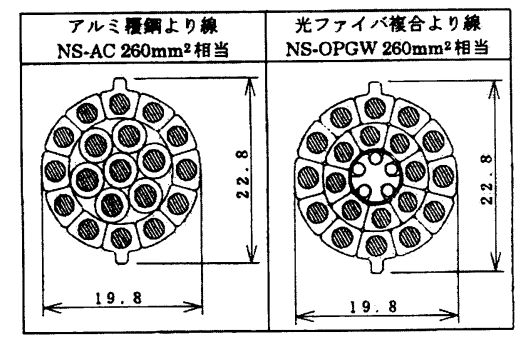

図 16. 低風音架空地線の形状

\section{$3.31,000 \mathrm{k} \mathrm{V}$ 線路用風音対策 ${ }^{3)}$}

\subsection{1 開発背景}

$1,000 \mathrm{k} \mathrm{V}$ 送電線は将来の電力需要増加への対応の ため、電源の広域開発、大電力を少ないルートで安定 供給するために建設が進められた。

送電線はコロナ協調面から 8 導体が採用され、スパ イラルロッド密着 2 条対角巻き対策の場合、標準の $600 \mathrm{~m}$ 径間では $2.5 \mathrm{~m}$ のスパイラルロッドが 5 万本程度 必要になる。電線架線後から運転開始前の短期間に集 中施工するには、施工力の確保が極めて難しい状況に あるため、低騒音電線のニーズが高まった。

\subsection{2 形状検討}

$1,000 \mathrm{k} \mathrm{V}$ 送電線は表面電位傾度が高くなるため、突 起部の水切れ性改善を目的に、突起部を模擬して、溝 幅、溝哚さの最適化検討が行なわれた。

試験から溝幅、溝の素線数、溝媣さをパラメータに、 水滴 10 個の落下時間で特性を評価した。

試験結果から次図の溝深さ $1.7 \mathrm{~mm}$ 、突起部開き角 $45^{\circ}$ の低騒音電線 LN-ACSR $960 \mathrm{~mm}^{2}$ が試作された。

\begin{tabular}{|c|c|c|}
\hline \multicolumn{2}{|l|}{ 绕元 } & $L \mathrm{~L}-\mathrm{ACSR} 960-\mathrm{C}^{2}$ \\
\hline \multicolumn{3}{|c|}{ 上り措鹪造图 } \\
\hline \multirow{2}{*}{ 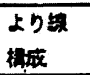 } & フルミ沗 & $4.8 \sim 6.26 \mathrm{~m} 3 \times 44$ 本 \\
\hline & 대 & $3.2 \mathrm{mE} \times 7$ 本 \\
\hline \multicolumn{2}{|c|}{ 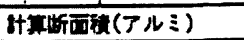 } & $961.5 m^{2}$ \\
\hline \multicolumn{2}{|c|}{ 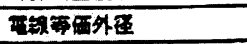 } & 40.30 \\
\hline \multicolumn{2}{|c|}{ m矮量 } & 3. $108 \mathrm{~kg} / \mathrm{a}$ \\
\hline \multicolumn{2}{|l|}{ 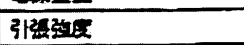 } & $20.440 \mathrm{~kg}$ \\
\hline \multirow[t]{2}{*}{ 恶流容量 } & in $\left(90^{\circ} \mathrm{C}\right)$ & 1.3381 \\
\hline & 短持成 $\left(120^{\circ} \mathrm{C}\right.$ & $1.820 \mathrm{~A}$ \\
\hline
\end{tabular}

図 17. 低騒音電線 LN-ACSR960 $\mathrm{mm}^{2}$ の諸元

\subsection{3 風音特性}

大型低騒音風洞を用いて LN-ACSR960 $\mathrm{mm}^{2} \times 8$ 導体 の風音特性を風速 $20 \mathrm{~m} / \mathrm{s}$ で評価した。

標準 ACSR $810 \mathrm{~mm}^{2} \times 8$ 導体と比較し、スパ イラルロド対 策と同等の $10 \mathrm{~dB}$ 程度の風音低減効果が確認された。

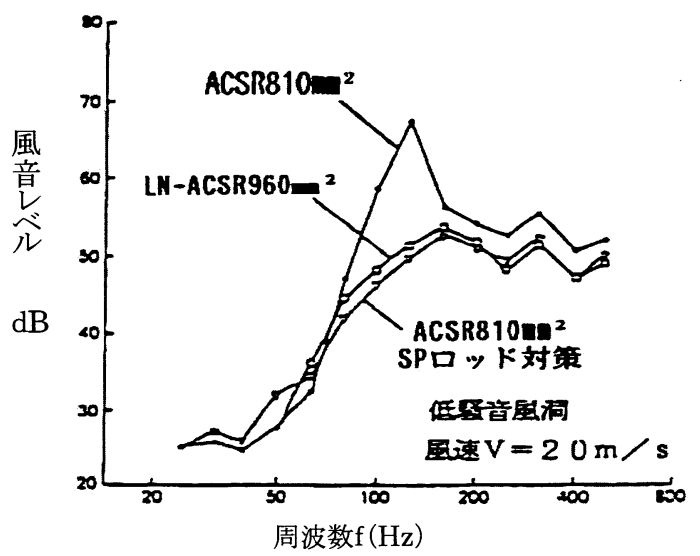

図 18. LN-ACSR $960 \mathrm{~mm}^{2}$ の風音スペクトル 3$)$

\subsection{4 コロナ特性}

LN-ACSR960 $\mathrm{mm}^{2} \times 8$ 導体の等価軽雨時ハム音レベ ルが電力中央研究所コロナケージで測定された。

LN-ACSR960 $\mathrm{mm}^{2} \times 8$ 導体の等価軽雨時コロナハム 音レベルは従来 ACSR $810 \mathrm{~mm}^{2} \times 8$ 導体と同等程度で あることが確認された。3) 10)

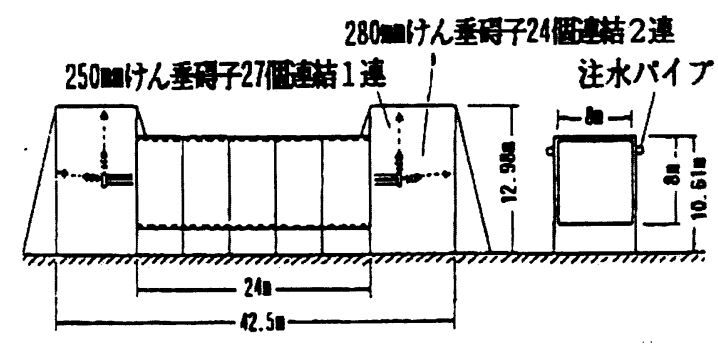

図 19. コロナ騒音測定用コロナケージ ${ }^{10)}$ 


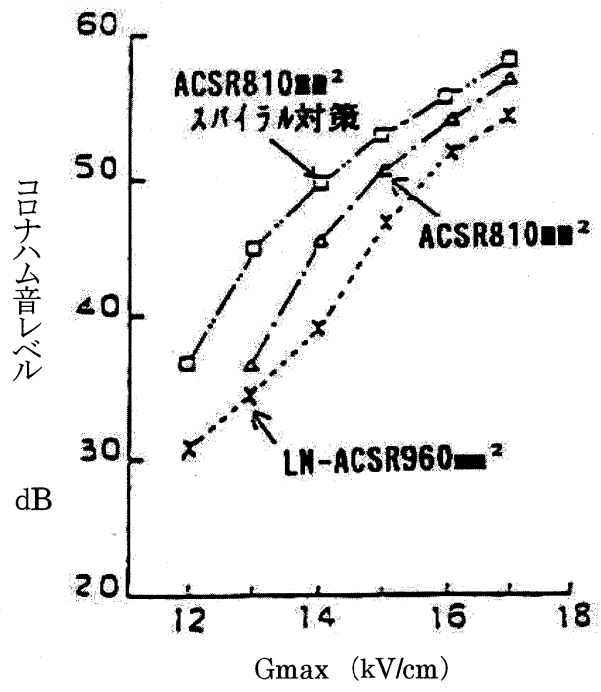

図 20. コロナハム音特性（等価軽雨時）

\subsection{5 空力特性}

LN-ACSR960 $\mathrm{mm}^{2} \times 8$ 導体の空気抵抗係数は設計風 速 $40 \mathrm{~m} / \mathrm{s}$ で ACSR $810 \mathrm{~mm}^{2} \times 8$ 導体と同等以下である。

従来のスパイラルロッド詨策よりも $15 \%$ 以上風圧 の低減することが明らかになった。 ${ }^{3)}$

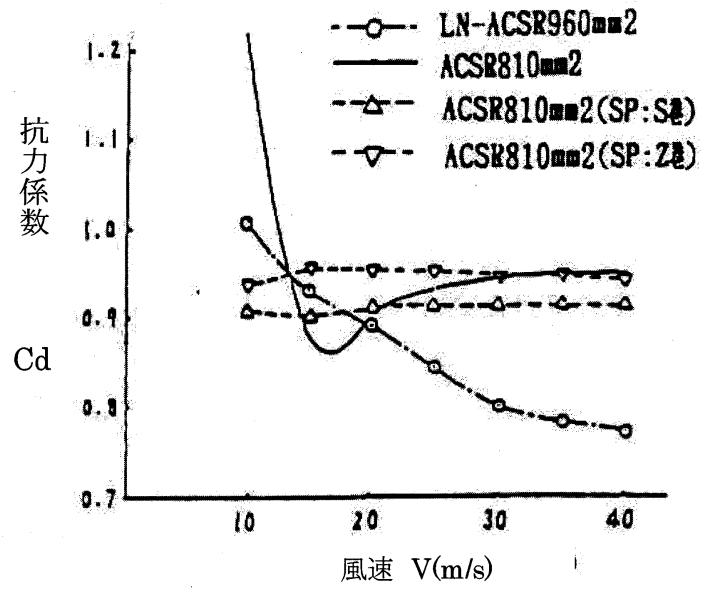

図 21. LN-ACSR $960 \mathrm{~mm}^{2} \times 8$ 導体の空気抵抗係数

\subsection{6 着雪特性}

自然降雪を用いた人工着雪風洞実験により低騒音 電線の着雪特性を評価した。

電線は径間長の㨝れ剛性を模擬したトルクで回転 可能なバネを設置してあり、次の結果が得られた。

1) LN-ACSR960 mm² は平滑部で着雪が円周方向に滑 り、突起部で分割されて脱落する傾向が認められる。

2) LN-ACSR960 $\mathrm{mm}^{2}$ は多導体として使用する限り、捻 り剛性により筒雪になる前に脱落するため、 ACSR $810 \mathrm{~mm}^{2}$ と有意差が認められない。

\subsection{7 付属品}

低騒音電線は突起部を有しているため異型断面と なるが、付属品に関しては若干の改良で標準品の適用 が可能であり、施工工具も既存品の活用が出来るよう に工夫が行われた。

表 1 . 付属品及び工具の適用

\begin{tabular}{|c|c|}
\hline 項 目 & 適用状況 \\
\hline 引留行 & 810票準品外堡を $\phi 72 \operatorname{ma~} 4$ m拡大 \\
\hline クラン任縮 & 本体は眼存品、タイスは 3 mø偏平型 \\
\hline カ4T0\%ク & 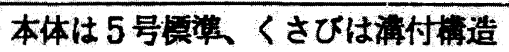 \\
\hline 金 & $\phi 600$ m栖準ウレタン品で問題なし \\
\hline 延線車 & 既存品て十分使用可能 \\
\hline
\end{tabular}

4. 最近の対策電線品開発例

4.1 丸素線型低騒音電線

\subsection{1開発の考え方}

超高圧の多導体架空送電線路新設の際は、環境を配 慮した低騒音電線が線路設計時に取り上げられている。

$1,000 \mathrm{k} \mathrm{V}$ 線路用として開発された突起部に溝部を 有する低騒音 LN-ACSR は多種類の圧縮成形素線を組 合わせているため、コストアップとなっている。

そこで、最外層の突起部と平滑部をすべて丸素線の 組合わせで構成した電線の特性評価を実施した。11)

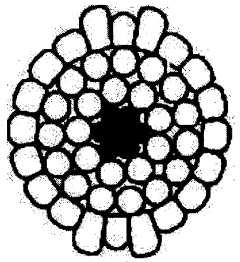

(a) 従来型 LN 電線

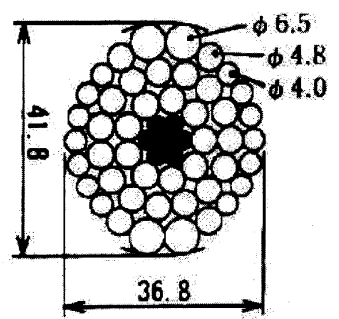

(b) 丸素線型 R-LN 電線
図 22. 丸素線型 RLN 電線と従来型 LN 電線の比較

\subsection{2 風音特性}

丸素線型 RLN810 $\mathrm{mm}^{2} \times 4$ 導体（導体間隔 $500 \mathrm{~mm}$ ) の風音特性に関して、低騒音風洞により、風向風速を パラメータとして実験が行なわれた。

RLN 電線は直角、斜風ともに特定の風速でスペクト ルの卓越は認めらず、従来型 LN 電線と概略同等性能 と評価される。風速 $20 \mathrm{~m} / \mathrm{s}$ 、直角風の例を示す。11) 


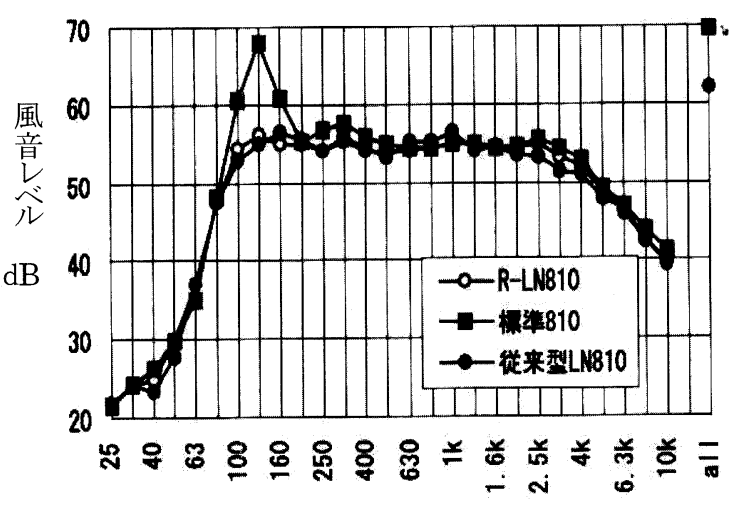

周波数 $\mathrm{f}(\mathrm{Hz})$

図 23. RLN-ACSR $810 \mathrm{~mm}^{2}$ の風音特性

\subsection{3 コロナ特性}

RLN810 mm² の等価軽雨時コロナハム音特性は従来 型 LN 電線と同等程度の性能であることが確認された。

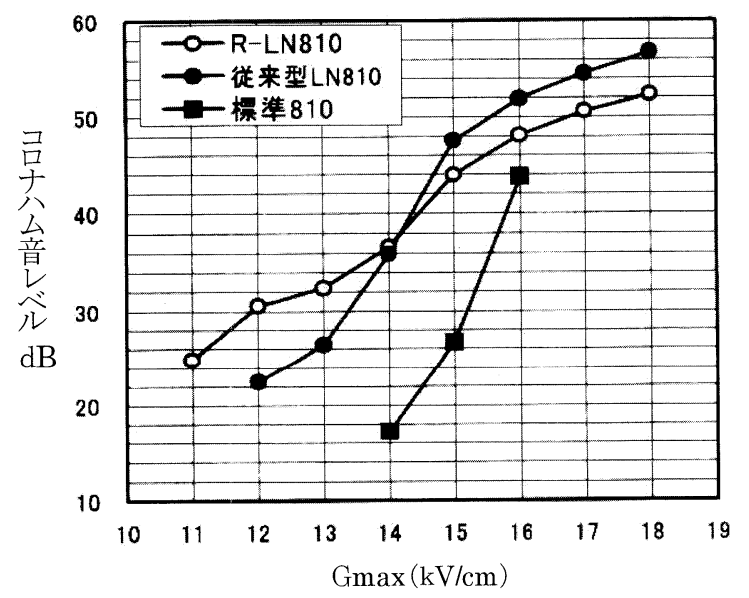

図 24. RLN-ACSR810 $\mathrm{mm}^{2}$ の等価軽雨時 コロナハム音特性 ${ }^{11)}$

\section{2 低風圧低風音電線}

送電線の風圧荷重低減と風騒音の低減効果を併せ 持つ、楕円断面を一定ピッチで捻回した電線が開発さ れている。風音低減効果はスパイラルロッド対策と同 等の効果が確認されている。

着雪が長手方向に不均一付着し、揚力のキャンセル 効果によりギャロッピング抑止効果が期待される。

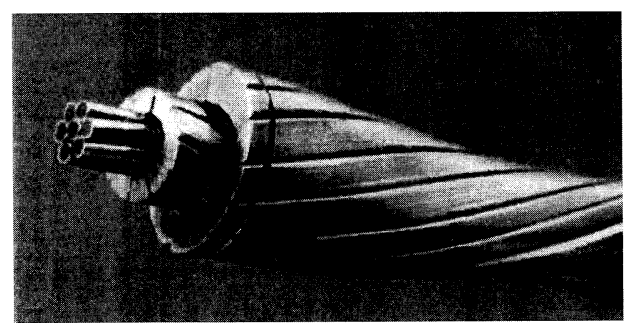

図 25. 低風圧低風音捻回楕円型電線

\section{5. がいし風音}

5.1 がいし風音の特徴

がいし風音は強風地区のがいし装置から発生し、 「ポー」あるいは「ピー」という汽笛やサイレンのよ うな音が断続的に聞こえるのが特徴である。

がいし風音はがいし種類により異なるが、個数が 4 〜 6 個以上で発生し、周波数は $400 \sim 800 \mathrm{~Hz}$ 程度、共 鳴風速は次図のように飛び飛びとなっている。

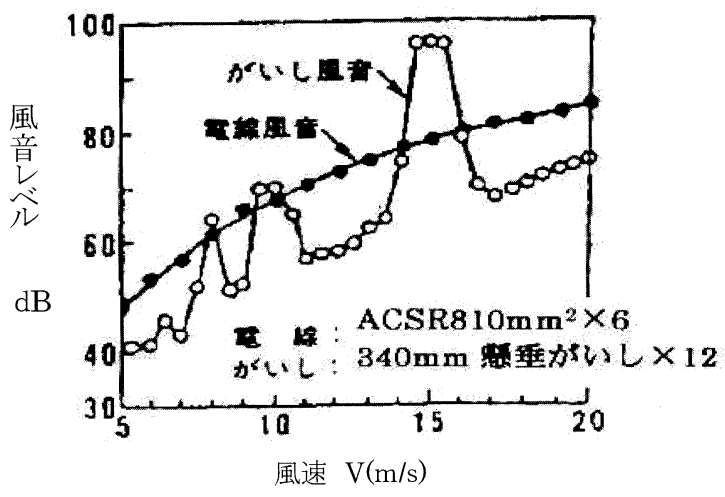

図 26. がいし風音の発生風速の特徴

5.2 がいし風音の発生メカニズム

がいし風音の発生メカニズムはがいしひだ部で発 生するキャビティ・トーン振動と呼ばれる流体音に起 因すると考えられ、がいし笠間の共鳴周波数と一致す ると、隣接するがいし笠間で共鳴が増幅されて最終的 に大きな風音になると推定されている。4)

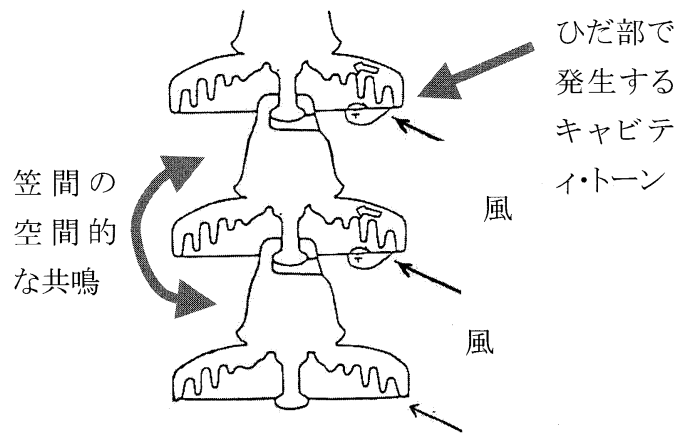

図 27. がいし風音発生メカニズム（推定）

5.3 がいし風音対策技術

がいし風音対策方法としては、

1）がいし連結部ボールソケット部にゴムキャップを 装着し、がいし同士の音響的結合を低減する方法。

2）長連がいしの場合には、最外ひだの内側に波型シ リコンシートを貼付け、渦振動を抑止する方法。

3 ）がいしひだ部の高さを変えて、キャビティ・トー ンの発生を抑止する方法。

等が開発されている。4) 


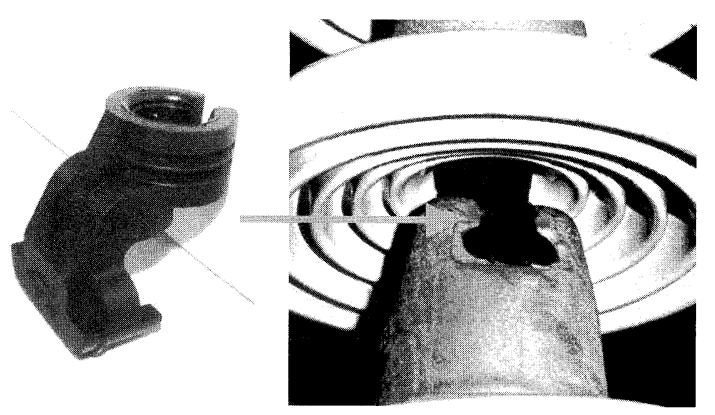

図 28. がいし風音防止キャップ取付状況

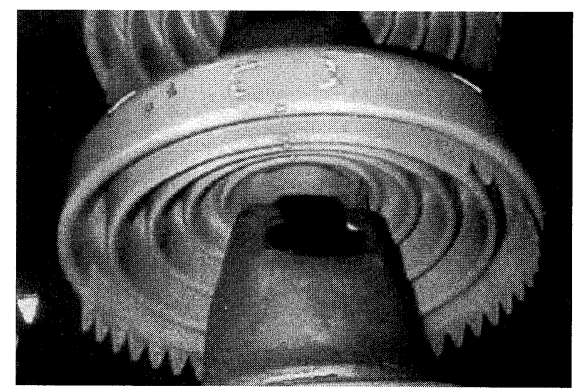

図 29. がいしひだ部への波型シリコン設置状況

\section{6. 鉄塔風音}

\section{1 鉄塔風音の特徵}

送電線路の超高圧化に伴なう鉄塔の大型化や市街 地との接近化等により、強風発生地区でかつ暗騒音が 低い場所では鉄塔風音の発生する場合がある。

現地で観測した風音のスペクトル例によると広い周 波数帯域にレベルの上昇が認められる。5)

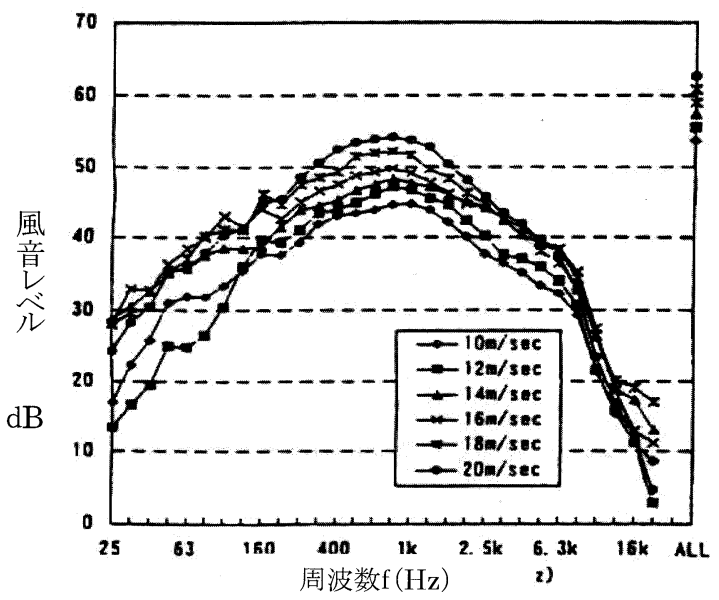

図 30. 鉄塔から発生する風音スペクトル測定例

\section{2 鉄塔鋼管共鳴音}

鋼管鉄塔の場合、鋼管部材の端部が開放されている と、気柱共鳴により風音の発生する場合がある。

管端をステンレス板、ゴム栓などを用いて塞ぐこと により共鳴音を防止することが可能である。

鋼管共鳴音の風音スペクトル例を示す。

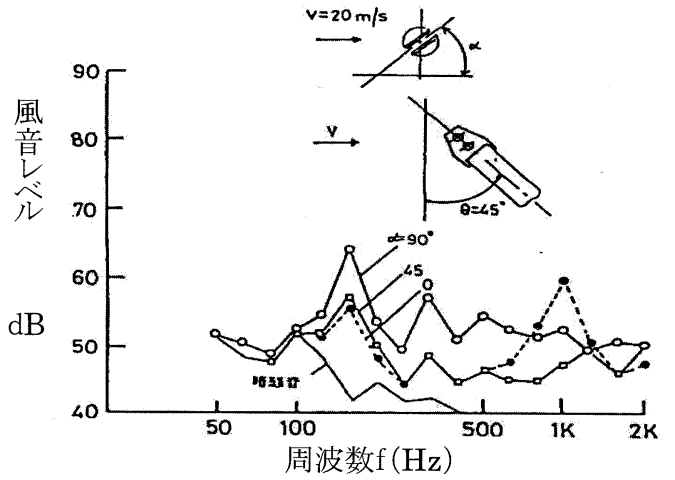

図 31。鋼管共鳴音スペクトル例

7. おわりに

架空送電線路の建設においては、環境に配慮した線 路設計が重要な位置付けとなっており、本稿では強風 時に発生する電線風騒音対策を中心に、その取組み例 を紹介した。

地球環境に優しい技術や製品が求められる傾向は今 後益々強くなると思われ、これまでに開発されてきた 風騒音低減技術の忘用展開が求められている。 参考文献

1）山崎他、「架空送電線と風音」、電気評論 1975.12

2）関屋他、「低風音・低 $\mathrm{AN}$ 電線の開発」、日立電線 No.6, 1986-12

3）赤木他、「電線から発生する風音及びコロナ騒音 対策技術」、CIGRE-SC22 仙台、1997

4）池田他、「高強度耐塩用がいし連から発生する風 騒音の低減技術」、電気学会論文誌 Vol.123-B, 平 15

5）長谷他、「鉄塔風音の発生メカニズムに関する研 究」、CIGRE-SC22

6) $\mathrm{N}$ Curle, "The influence of solid boundaries upon aerodynamic sound",Proc,Roy.Soc,London, 1952

7) OM Phillips, "The intensity of Aeolian tones" J Fluid Mech.1, p.607-624, 1956

8）山本他、「送電線路の風騒音・コ叶騒音対策技術」、 電線・ケーブル研究会、電気学会、1994

9）送電線用新種電線専門委員会、「送電用新種電線」、 電気共同研究第 43 巻第 3 号、1988

10) Tanabe K, "Experimental Study on the Prediction of Hum Noise from Conductor Bundles for UHV Transmission Lines", Electrical Engineering in Japan, Vol.125, No.1, 1998

11) 北嶋他、「 $500 \mathrm{kV}$ 送電線用丸素線型低騒音電線の開 発」、電気学会全国大会、2001 